\section{College of the Pharmaceutical Society}

THe College of the Pharmaceutical Society of Great Britain has continued in its temporary aceommodation in Cardiff, being distributed between University College and the Medical Unit of the Royal Infirmary, with the Pharmacological Laboratories and Department of Nutrition under the direction of Dr. K. H. Coward at the National Institute of Research in Dairying, Reading. The chair of pharmacology, left vacant by the appointment of Prof. J. H. Gaddum to Edinburgh, has not yet been filled. Although the College has lost many of its research workers, who left for some form of national service during 1942-43, it is gratifying to see that a large output of research work is still being maintained, as judged by the "Annual Report of Research Work" covering the period January 1942-June 1943, which has recently been issued.

\section{Two Czech Chemists}

THE Association of Czechoslovak Scientists and Technicians and the Czechoslovak Research Institute, London, have issued a pamphlet with the above title, by Dr. G. Druce (New Europe Publishing Co., 29 St. James's Street, London, S.W.1. Pp. 67. 3s.6d.). It describes the life and contributions to science of Prof. Bohuslav Brauner (1855-1935) and the less known Frantisek Wald (1861-1930). An adequate account is given of Brauner's work in inorganic chemistry, which centred around the Periodic Law; and the theoretical views of Wald on stoichiometry and the theory of phases (which were highly rated by 0stwald) are explained in an intelligible way. The work, which has useful bibliographies, is a significant and interesting contribution to the history of chemistry.

\section{Lady Tata Memorial Trust Awards}

The Trustees of the Lady Tata Memorial Fund announce that, on the recommendation of the Scientific Advisory Committee, they have agreed, if circumstances permit, to make the following awards for research in blood diseases, with special reference to leukæmia, in the academic year beginning on October 1, 1944: grants for research expenses to Prof. L. Doljanski (Jerusalem), Dr. J. Furth (New York), Dr. P. A. Gorer (London), Dr. A. H. T. RobbSmith (Oxford); part-time personal grant and grant for research expenses to Dr. W. Jacobson (Cambridge).

\section{University of London}

Prof. Frank Horton has been re-elected vicechancellor of the University of London. Recent appointments in the University include the following: Dr. H. B. Acton, lecturer in philosophy at Bedford College, to the University chair of philosophy tenable at Bedford College. Dr. H. T. Flint, reader in physies at King's College, to the Hildred Carlile chair of physies tenable at Bedford College. Dr. W. N. Bailey, lecturer in mathematics in the University of Manchester, to the University chair of mathematics tenable at Bedford College. The title of reader in zoology in the University has been conferred on Mr. G. P. Wells in respect of the post held by him at University College. The degree of D.Sc. has been conferred on E. J. Irons (Queen Mary College), A. G. Quarrell (Imperial College), R. W. Powell and R. H. Common.
The following, among others, have been appointed fellows of King's College: Dr. T. Loveday, vicechancellor of the University of Bristol; Dr. R. E. Priestley, principal and vice-chancellor of the University of Birmingham; Sir Hector Hetherington, principal and vice-chancellor of the University of Glasgow; and Dr. J. Henderson, sub-dean of the Faculty of Science of the College.

\section{Summer School in Health Education}

In response to requests from the Ministry of Health and the Board of Education, and in order to reduce the strain on the country's transport system, the Central Council for Health Education has decided not to proceed with its Durham School, and to limit attendance at the London School (August 9-19) to students from London and the Home Counties. Details of the London School may be obtained from the Medical Adviser and Secretary, Central Council for Health Education, Tavistock House, Tavistock Square, London, W.C.I.

\section{Announcements}

DR. H. G. SANDERS, lecturer in agriculture in the University of Cambridge, has been appointed professor of agriculture in the University of Reading, in succession to Prof. R. Rae.

LoRD HaILEx has been elected president of the Research Defence Society.

By authorization of the University Court, the Department of Chemistry in relation to Medicine in the University of Edinburgh, the head of which is Prof. G. F. Marrian, will in future be known as the Department of Biochemistry.

Dr. C. J. SMIThells has been appointed director of research of the British Aluminium Co., Ltd., and will take up his duties in August next. Dr. Smithells was an original member of the research staff of the General Electric Co., Ltd., which he left in 1938 to become general manager of Lodge Plugs, Ltd. $\mathrm{He}$ is the author of several books on metallurgical subjects. Dr. A. G. C. Gwyer, the scientific manager of the British Aluminium Co., will reach the retiring age in October 1945, after thirty-three years' service with the Company. During the intervening period he will remain in a consultative capacity in order to assist Dr. Smithells to become conversant with the many problems arising in the Company's research activities.

THE exhibition "Chemicals in War and Reconstruction" organized by the Association of Scientific Workers, will be on view in the Art Gallery, Hudders- field, during the week July 7-14 between 10 a.m. and $7.30 \mathrm{p.m}$. It will be opened at $6 \mathrm{p.m}$. on July 6 by Mr. G. B. Jones, chairman of the Yorkshire Section of the Society of Chemical Industry.

IN connexion with the article "Freedom from Want of Food" in Nature of June 17, p. 750, Sir Jack Drummond writes: "I did not say that far more milk is being produced to-day than before the War; I directed attention to the rise in consumption of liquid milk that has occurred since 1939. As shown in a recent Ministry of Food publication : 'Food Consumption Levels in the United States, Canada and the United Kingdom', H.M. Stationery Office, 1944, the consumption of milk products in the United Kingdom, excluding butter, in 1943 was 28 per cent greater than in the years immediately before the war". 